\title{
PENGARUH SUPPLY CHAIN MANAGEMENT TERHADAP KINERJA PERUSAHAAN MELALUI KEUNGGULAN BERSAING
}

\author{
Wulandari dan Ria Nelly Sari dan Al Azhar L \\ Program Studi Sarjana Ekonomi Universitas Riau \\ Fakultas Ekonomi Universitas Riau \\ Email: wulandari0494@gmail.com
}

\begin{abstract}
This research aims to examine the effect of supply chain management on firm performance. In this study, the effect of supply chain management on firm performance is intervened by competitive advantage. The sample of this study is manufacturing firms listed on Bursa Efek Indonesia (BEI) 2014. By using total sampling procedure, 137 firms were selected as a sample and questionnaires were sent to finance,production or marketing manager through corporate secretary. From 137 set questionnaires were sent, 64 sets were returned and due to missing data/incomplete answer so only 59 sets were analyzed. Data was analyzed by using SPSS program version 20.0. This study found that supply chain management positively effect firm performance. The findings showed that supply chain management positively effect the firm's competitive advantage. Further, analyzed found that competitive advantage positively effect firm performance. Meanwhile, the results proved that $\beta$ value of relationship between the supply chain management and firm performance after entered by competitive advantage was decreased from 0.825 to 0,412 . This research conclude that competitive advantage has a role as partial mediation variable.
\end{abstract}

Keywords: Supply Chain Management (SCM), Firm Performance, Competitive Advantage

\begin{abstract}
Abstrak: Penelitian ini bertujuan untuk menguji pengaruh supply chain management terhadap kinerja perusahaan. Dalam penelitian ini, pengaruh supply chain management terhadap kinerja perusahaan diintervening oleh keunggulan bersaing. Sampel dalam penelitian ini adalah seluruh perusahaan manufaktur yang terdaftar di Bursa Efek Indonesia (BEI) tahun 2014. Dengan metode total sampel, 137 perusahaan terpilih sebagai sampel dan kuesioner dikirim kepada manajer keuangan, produksi atau pemasaran melalui corporate secretary. Dari 137 kuesioner yang dikirim, 64 set kembali dan karena data yang hilang / jawaban yang tidak lengkap maka hanya 59 set yang dapat dianalisis. Data dianalisis menggunakan program SPSS versi 20.0. Penelitian ini menemukan bahwa supply chain management berpengaruh positif terhadap kinerja perusahaan. Hasil menunjukkan bahwa supply chain management berpengaruh positif terhadap keunggulan bersaing. Lalu, analisis juga menemukan bahwa keunggulan bersaing berpengaruh positif terhadap kinerja perusahaan. Sementara itu, hasil membuktikan bahwa nilai $\beta$ hubungan antara supply chain management dan kinerja perusahaan setelah dimasukkannya variabel keunggulan bersaing menjadi lebih kecil dari 0,825 menjadi 0,412. Penelitian ini menyimpulkan bahwa keunggulan bersaing berperan sebagai partial mediation variable.
\end{abstract}

Kata kunci: Supply Chain Management, Kinerja Perusahaan, Keunggulan Bersaing 


\section{PENDAHULUAN}

Era globalisasi dan informasi menyebabkan dunia persaingan global menjadi semakin ketat. Kecenderungan lingkungan bisnis yang semakin berubah, kemajuan sistem informasi, teknologi serta lingkaran hidup produk yang semakin pendek menyebabkan konsumen mengharapkan standar produk yang lebih tinggi. Konsumen telah menjadi pertimbangan yang sangat berpengaruh bagi suatu perusahaan pada era globalisasi ini, terlebih dengan banyaknya perusahaan-perusahaan lain yang dapat mengancam loyalitas konsumen. Dengan bertambah ketatnya persaingan dan semakin beragamnya selera konsumen menuntut perusahaan yang telah lama ada untuk tetap dapat bertahan agar dapat bersaing dengan perusahaan-perusahaan baru yang terus bermunculan. Kompetisi yang dewasa ini terjadi mengharuskan perusahaan menciptakan strategi agar tetap bisa bertahan dan memiliki daya saing untuk lebih unggul dari pesaing-pesaing. Dalam membangun competitive advantage, perusahaan disarankan untuk membentuk sebuah sistem yang unik dan memiliki keunggulan dibandingkan dengan pesaing (Heizer \& Render, 2004). Pada intinya, keunggulan bersaing perusahaan adalah tentang bagaimana perusahaan dapat memberikan nilai yang baik bagi konsumen dengan efisien dan dapat mempertahankannya dalam persaingan global. Hal tersebut mengharuskan perusahaan menciptakan strategi agar tetap bisa bertahan dan memiliki daya saing untuk lebih unggul dari pesaing-pesaing. Strategi bersaing merupakan cara menentukan posisi paling menguntungkan dalam industri, tempat paling tepat dalam persaingan. (Porter, 1985:1).

Strategi dalam rangka pencapaian daya saing yang tinggi sangat tergantung dari efisiensi dan produktivitas antar area fungsi dalam perusahaan, untuk lebih responsif terhadap kebutuhan konsumen dan permintaan pasar. Bukan hanya tingginya kualitas produk yang disampaikan kepada konsumen yang menjadi fokus perusahaan, tetapi juga strategi pengiriman produk yang cepat. Atas dasar hal tersebut maka dibutuhkan jejaring bisnis atau manajemen rantai pasokan (supply chain management/SCM) yang efektif (Suhartati dan Hilda, 2012). Supply chain management adalah seperangkat pendekatan yang diterapkan untuk mencapai efisiensi integrasi supplier, manufaktur, gudang, dan penyimpanan, sehingga barang dapat diproduksi dan didistribusikan dalam jumlah yang tepat, lokasi yang tepat, waktu yang tepat untuk meminimalkan biaya dan memberikan layanan yang memuaskan untuk konsumen (Levi, 2000).

Di tengah perkembangan era globalisasi dan informasi, industri manufaktur Indonesia tetap mengalami akselerasi. Badan Pusat Statistik (BPS) melaporkan produksi Industri Manufaktur Besar dan Sedang (IBS) tumbuh 4,96 persen pada kuartal III 2014 dibandingkan dengan pencapaian periode yang sama tahun 2013. Secara tahunan, Kepala BPS Suryamin menjelaskan membaiknya kinerja manufaktur terutama disebabkan oleh meningkatnya produksi sejumlah sektor, yakni industri peralatan listrik tumbuh 13,21 persen, industri mesin dan perlengkapan naik 9,49 persen, serta industri berbasis kayu dan anyaman meningkat 8,7 persen (dalam CCN Indonesia).

Banyak faktor yang dapat meningkatkan produksi perusahaan seperti peningkatan kualitas sumber daya manusia, penigkatan kualitas bahan baku, dan berkurangnya tingkat kegagalan produksi pada perusahaan. Kualitas bahan baku erat kaitannya dengan supplier. Interaksi perusahaan dengan supplier untuk mendapatkan bahan baku yang digunakan untuk produksi merupakan salah satu aktivitas yang berhubungan erat dengan rantai pasokan atau supply chain management. Pengelolaan kegiatan-kegiatan operasional perusahaan dalam rangka memperoleh barang mentah, mengolah barang mentah tersebut 
menjadi barang dalam proses dan/atau barang jadi, kemudian mengirim barang tersebut ke konsumen melalui sistem distribusi merupakan kegiatan yang diintegrasi dalam supply chain management (Heizer dan Render, 2004).

Penelitian ini akan menguji mengenai hubungan antara supply chain management terhadap kinerja perusahaan. Pengaruh supply chain management terhadap kinerja perusahaan telah diuji secara empirik dalam penelitian Li, et al., (2006); Suharto, (2013); Ariani, (2013). Dalam penelitian ini, akan ditambahkan variabel keunggulan bersaing sebagai variabel intervening dalam menguji pengaruh supply chain management terhadap kinerja perusahaan dengan anggapan bahwa keunggulan bersaing merupakan suatu batu lompatan bagi perusahaan untuk mencapai kinerja yang baik. Hal tersebut didukung oleh pendapat Day dan Wensley (1988) menyatakan bahwa keunggulan bersaing merupakan bentuk-bentuk strategi untuk membantu perusahaan dalam mempertahankan kelangsungan hidupnya. Keunggulan dalam bersaing merupakan sarana untuk mencapai tujuan akhir perusahaan yaitu meningkatkan kinerja perusahaan. Penelitian terdahulu menunjukkan bahwa supply chain management berpengaruh terhadap keunggulan bersaing (Li, et al., 2006; Henriksson, 2005; Bratic, 2011; Rahmasari, 2011; Suharto, 2013). Merujuk pada penelitian yang telah dilakukan sebelumnya, maka penelitian ini akan menguji peran variabel keunggulan bersaing sebagai full mediation atau partial mediation dalam menguji pengaruh supply chain management terhadap kinerja perusahaan.

\section{KAJIAN TEORI}

Supply Chain Management. Supply chain management adalah seperangkat pendekatan yang diterapkan untuk mencapai efisiensi integrasi supplier, manufaktur, gudang, dan penyimpanan, sehingga barang dapat diproduksi dan didistribusikan dalam jumlah yang tepat, lokasi yang tepat, waktu yang tepat untuk meminimalkan biaya dan memberikan layanan yang memuaskan konsumen (Levi, 2000). Rantai pasokan mencakup keseluruhan interaksi antara pemasok, perusahaan manufaktur, distributor, dan konsumen. Interaksi ini juga berkaitan dengan transportasi, informasi penjadwalan, transfer kredit, dan tunai, serta transfer bahan baku antara pihak-pihak yang terlibat (Siagian, $2005: 9$ ).

Dalam prosesnya, strategi supply chain management memilik tiga tujuan. Tujuan penerapan supply chain management yang pertama adalah cost reduction, supply chain management yang dijalankan perusahaan harus dapat meminimalkan biaya logistik yang terjadi, misalnya dengan memilih alat/model transportasi, penggudangan, standar, dan layanan yang meminimalkan biaya. Kedua, supply chain management bertujuan untuk capital reduction yang ditujukan untuk meminimalisasikan tingkat investasi dalam strategi logistik. Strategi ini dapat menghasilkan biaya variabel yang lebih tinggi dari pada strategi yang membutuhkan level yang lebih tinggi untuk investasi, tetapi pada saat pengembalian investasi diharapkan dapat meningkat. Ketiga, penerapan supply chain management diharapkan dapat memperbaiki pelayanan secara terus menerus (service improvement) (Siagian, 2005:22-23).

Menurut Siagian (2005:23-27) dalam bukunya yang berjudul "Aplikasi Supply Chain Management dalam Dunia Usaha" menyatakan bahwa perencanaan supply chain management terdiri dari enam topik. Topik pertama adalah tingkatan perencanaan. Perencanaan supply chain management bertujuan untuk menjawab pertanyaan what (apa), when (kapan), how (bagaimana), hal tersebut berlangsung pada tiga tingkatan, yaitu strategis, taktikal, dan operasional. Perbedaan utama antara tingkatan tersebut ditentukan 
oleh waktu perencanaan. Perencanaan strategis, digolongkan sebagai rencana jangka panjang logistik, diaman waktu yang dibutuhkan lebih dari satu tahun. Perencanaan ini biasanya berhubungan dengan kebijakan-kebijakan perusahaan dalam menjalankan perusahaan. Perencanaan taktis, merupakan perencanaan logistik jangka menengah, biasanya berlaku pada jangka waktu menangah yang tidak lama, kurang dari satu tahun. Perencanaan operasional, berorientasi pada kegiatan operasional logistik sehari-hari, sehingga jangka waktunya sangat pendek, bahkan bisa direncanakan secara harian atau jam. Topik kedua, luasnya daerah perencanaan. Kegiatan logistik menyangkut empat keputusan penting, yaitu tingkat layanan kepada pelanggan; lokasi fasilitas logistik, yaitu menentukan strategi logistik dapat berjalan dengan lancar dan menjamin akan mendapatkan stock; keputusan persediaan yang berkaitan dengan persediaan yang dimiliki dan kecukupan stock barang; keputusan transportasi, yaitu memilih model transportasi yang akan digunakan. Topik ketiga, tujuan pelayanan konsumen. Faktor tujuan pelayanan konsumen sangat berbeda dengan faktor lainnya, bagaimana usaha untuk memenuhi pelayanan konsumen sangat membutuhkan "seni". Pada tingkat pelayanan jasa yang rendah pemusatan persediaan dapat dilakukan di beberapa tempat, akibatnya biaya menjadi lebih mahal. Tetapi, pada usaha dengan pelayanan jasa yang tinggi maka akan terjadi sebaliknya. Topik keempat, strategi fasilitas lokasi. Strategi fasilitas lokasi ini sangat tergantung pada posisi geografis dari tempat penyimpanan dan tempat sumber daya. Menetapkan jumlah, lokasi, besarnya fasilitas, dan menentukan pasar yang dituju adalah cara penentuan produk yang tepat untuk dipasarkan. Menentukan biaya rendah atau mendapatkan keuntungan yang maksimal adalah tujuan dari perencanaan strategi fasilitas lokasi. Topik kelima, keputusan persediaan. Keputusan persediaan menunjukkan tata cara bagaimana persediaan diatur. Kebijakan yang diambil perusahaan biasanya mempengaruhi keputusan fasilitas lokasi, untuk itu kebijakan ini digolongkan sebagai strategi logistik. Keenam, strategi transportasi. Keputusan transportasi yang digunakan sangat bergantung pada mode, seperti ukuran pengiriman, rute pengiriman, dan penjadwalan.

Keunggulan Bersaing. Keunggulan bersaing adalah keuntungan lebih daripada pesaing yang diperoleh dengan menawarkan nilai konsumen yang lebih besar, baik harga yang lebih rendah atau dengan memberikan keuntungan lebih besar dan layanan yang membenarkan harga yang lebih tinggi (Porter, 1985). Keunggulan daya saing dapat diperoleh apabila perusahaan memiliki kemampuan untuk menyajikan setiap proses operasional bisnisnya secara lebih baik dalam menghasilkan barang dan jasa dengan kualitas tinggi dan harga yang bersaing. Sehingga produk yang dihasilkan mampu bersaing baik dari sisi kualitas, harga, penyerahan produk, dan fleksibilitas dibandingkan pesaingnya di pasar (Heizer dan Render, 2004).

Keunggulan bersaing dapat direalisasikan jika perusahaan dapat mencapai keunggulan strategis, keunggulan taktis dan keunggulan operasional (McLeod, Jr., Raymond dan George P.Schell, 2011). Dalam hal mencapai tujuan dan unggul dari pesaing, perusahaan harus merumuskan strategi yang cocok dengan keadaan baik internal maupun ekternal perusahaan untuk kemudian diimplementasikan dalam persaingan dan menciptakan keunggulan dalam proses sehari-hari.

Untuk mencapai keunggulan bersaing, menurut Porter (1985:4-6) dalam bukunya Competitive Advantage: Creating and Sustaining Superior Performance yang juga dikutip dalam buku karangan Anthony dan Govindarajan (2012:75-76), perusahaan perlu memperhatikan lima kekuatan persaingan. Pertama, intensitas persaingan di antara para pesaing yang ada, faktor-faktor yang mempengaruhi persaingan secara langsung adalah 
pertumbuhan industri, perbedaan produk, jumlah dan keanekaragaman pesaing, tingkat biaya tetap, dan kendala untuk keluar dari industri. Kedua, daya tawar pelanggan. Faktorfaktor yang mempengaruhi daya beli adalah jumlah pembeli, biaya peralihan pembeli, kemampuan pembeli untuk mengintegrasikan kembali, dampak produk dari unit bisnis pada biaya total pembeli, dampak produk unit bisnis pada kualitas/kinerja produk pembeli dan signifikansi volume unit bisnis bagi pembeli. Ketiga, daya tawar pemasok. Faktorfaktor yang mempengaruhi kekuatan pemasok adalah jumlah pemasok, kemampuan pemasok untuk melakukan integrasi ke depan, kehadiran input substitusi, dan pentingnya volume unit bisnis bagi pemasok. Keempat, ancaman dari barang substitusi. Faktor-faktor yang mempengaruhi ancaman barang substitusi adalah harga/kinerja relatif barang substitusi, biaya peralihan pembeli, dan kecenderungan pembeli untuk menggunakan barang substitusi. Kelima, ancaman pendatang baru yang masuk industri. Faktor-faktor yang mempengaruhi kendala untuk masuk dalam industri adalah persyaratan modal, akses terhadap saluran distribusi, skala ekonomis, diferensiasi produk, kompleksitas teknologi dari produk atau proses, tindakan balasan yang diperkirakan dari perusahaan-perusahaan yang sudah ada, dan kebijakan pemerintah.

Porter (1985) kemudian melanjutkan bahwa ada tiga observasi yang dibuat sehubungan dengan analisis industri tersebut yaitu semakin kuat lima kekuatan tersebut, semakin rendah kemungkinan profitabilitas dari industri itu; bergantung pada lima kekuatan itu, masalah strategi kunci yang dihadapi oleh unit bisnis tersebut akan berbeda dari satu industri ke industri yang lain; dan memahami hakikat setiap kekuatan membantu perusahaan untuk merum uskan strategi yang efektif.

Analisis lima kekuatan persaingan merupakan titik awal untuk mengembangkan keunggulan persaingan karena ini membantu mengidentifikasi kesempatan dan ancaman dalam lingkungan eksternal. Dengan pemahaman ini, Porter (1985:11) mengklaim bahwa unit bisnis mempunyai cara generik untuk merespon kesempatan dalam lingkungan eksternal dan mengembangkan keunggulan bersaing yang berkesinambungan biaya rendah dan diferensiasi produk. Strategi biaya rendah berfokus pada bagaimana perusahaan dapat beroperasi dalam menghasilkan produk atau jasa dengan biaya yang relatif lebih rendah dibandingkan dengan pesaingnya. Diferensiasi produk mengacu pada kemampuan perusahaan untuk dapat menawarkan produk atau jasa yang unggul dan unik dibandingkan dengan produk atau jasa yang dihasilkan pesaing.

Kinerja Perusahaan. Kinerja adalah kemampuan kerja yang ditunjukkan dengan hasil kerja (Yurniwati, 2008). Kinerja perusahaan merupakan ukuran keberhasilan suatu perusahaan yang diukur setiap jangka waktu yang ditetapkan. Hasil ini dapat dikatakan suatu nilai dari setiap aktivitas yang telah disusun dan dilaksanakan untuk dapat mengidentifikasi apakah strategi yang telah dibuat dan pelaksanaan strategi tersebut telah tepat atau malah sebaliknya (Prakosa, 2005).

Target kinerja yang ditetapkan oleh perusahaan akan memotivasi personel untuk mencapai target tersebut. Target yang ditetapkan akan menjadi ukuran berhasil atau tidaknya perusahaan dan setiap anggota perusahaan dalam menjalankan kegiatan operasional. Kinerja yang baik akan berdampak pada keberlangsungan hidup perusahaan. Untuk tercapainya kinerja yang baik, maka diperlukan adanya penilaian kinerja. Penilaian kinerja juga digunakan untuk menekan dan mencegah perilaku yang tidak semestinya terjadi serta untuk merangcang dan menegakkan perilaku yang semestinya diinginkan, melalui umpan balik hasil kinerja pada waktunya serta penghargaan, baik yang bersifat 
intrinsik maupun ekstrinsik. (Chairani dan Wahyuni Lestari, 2011). Li, et al., (2006) menyatakan bahwa kinerja perusahaan dapat dinilai dari kinerja keuangan dan kinerja non-keuangan perusahaan.

Ventrakaman and Ramanujam (1986) menyatakan bahwa kinerja perusahaan dapat diukur dengan menggunakan tiga indikator yaitu kinerja keuangan, kinerja operasional, dan kinerja berbasis pasar. Kinerja keuangan pada umumnya diukur dengan pengukuran berbasis data akuntansi, seperti pengukuran profitabilitas yang meliputi pengembalian atas aset (return on assets), tingkat pengembalian atas investasi (return on investment), tingkat pengembalian atas penjualan (return on sales), dan tingkat pengembalian atas modal (return on equity). Pengukuran kinerja dari segi non-keuangan telah bertahun-tahun mendapatkan perhatian lebih seiring bertambah banyaknya jumlah perusahaan. Carton (2004) menyatakan bahwa keuntungan utama pengukuran kinerja operasional dibandingkan dengan kinerja keuangan adalah ketika informasi yang tersedia terkait dengan peluang yang telah ada, namun belum terealisasi secara keuangan. Kinerja operasional umumnya dapat diukur menggunakan pengukuran seperti pangsa pasar (market share), peluncuran produk baru, kualitas produk/jasa, efektivitas pemasaran, dan kepuasan pelanggan (Ventrakaman and Ramanujam, 1986). Kinerja berbasis pasar secara keseluruhan akan terpengaruh ketika pasar mengetahui informasi mengenai operasional perusahaan yang tidak termasuk dalam hasil kinerja perusahaan. Tingkat pengembalian kepada pemegang saham, market value added dan keuntungan tahunan dapat digunakan untuk mengukur kinerja berbasis pasar (Carton 2004).

\section{METODE}

Populasi dalam penelitian ini adalah perusahaan manufaktur yang terdaftar di Bursa Efek Indonesia tahun 2014. Jumlah perusahaan manufaktur yang terdaftar di Bursa Efek Indonesia tahun 2014 adalah sebanyak 137 perusahaan. Teknik pengambilan sampel yang digunakan dalam penelitian ini adalah teknik sampel jenuh atau juga dikenal dengan istilah sensus, yaitu menjadikan semua populasi sebagai sampel. Untuk mewakili perusahaan sebagai unit analisis dalam penelitian ini, maka responden dalam penelitian ini adalah manajer atau wakil/staff manajer pada bagian keuangan, produksi atau pemasaran.

Data dalam penelitian ini menggunakan data primer yang dikumpulkan dengan mengirimkan kuesioner kepada responden. Kuesioner dikirimkan kepada responden melalui corporate secretary via email, yaitu dengan menggunakan sistem aplikasi Google Forms, yang kemudian akan diteruskan kepada manajer keuangan, produksi atau pemasaran. Teknik analisis data dalam penelitian ini dilakukan dengan menggunakan pendekatan SPSS versi 20.0.

Dari 137 kuesioner yang dikirimkan terdapat 64 (46,71\%) kuesioner yang kembali dan sebanyak 73 kuesioner $(53,29 \%)$ kuesioner yang tidak mendapat respon. Dari kuesioner yang diterima tidak semuanya dapat dianalisis karena sebanyak 5 (3,65\%) dari total kuesioner yang dikembalikan tidak dapat digunakan karena kuesioner diisi oleh perusahaan yang sama. Kuesioner yang dapat diolah lebih lanjut sebanyak 59 kuesioner atau $43,07 \%$ dari total kuesioner yang dikirim. Tingkat pengembalian kuesioner secara ringkas dapat dilihat pada tabel berikut. 
Tabel 1. Tingkat Pengembalian Kuesioner

\begin{tabular}{lcc}
\hline Keterangan & Jumlah & Persentase \\
\hline Kuesioner yang disebar & 137 & 100 \\
Kuesioner yang kembali & 64 & 46,71 \\
Kuesioner yang tidak kembali & 73 & 53,29 \\
Kuesioner yang dapat dianalisis & 59 & 43,07 \\
Kuesioner yang tidak dapat di analisis & 5 & 3,65 \\
\hline
\end{tabular}

Sumber: Data Penelitian pada tahun 2015 (data olahan)

Kerangka Pemikiran. Pengaruh Supply Chain Management terhadap Kinerja Perusahaan. Supply chain management merupakan sarana pengoptimalan aktivitas perusahaan dalam kegiatan operasional perusahaan untuk meminimalkan biaya dan mencapai kepuasan pelanggan yang diwujudkan dengan menciptakan hubungan yang baik dengan supplier, produksi yang baik dan hubungan dengan pelanggan yang baik. Kegagalan dalam operasional perusahaan saat menghasilkan produk/jasa atau dalam level apapun dapat menyebabkan biaya kegagalan meningkat yang kemudian akan menyebabkan profitabilitas perusahaan menurun dan menyebabkan daya beli menurun pula. Supply chain management dapat meminimalisasi biaya yang dikeluarkan oleh perusahaan dan meningkatkan nilai mutu produk di mata pelanggan sehingga profitabilitas perusahaan akan meningkat. Kondisi ini diharapkan dapat meningkatkan kinerja perusahaan.

Supply chain management memilik tiga tujuan, yaitu cost reduction, capital reduction, dan service improvement (Siagian, 2005:23-27). Dari ketiga tujuan tersebut, tujuan cost reduction bermaksud bahwa dengan penerapan supply chain management perusahaan dapat meminimalkan biaya logistik yang terjadi, misalnya dengan memilih alat/model transportasi, cara atau sistem distribusi, penggudangan, standar, dan layanan yang meminimalkan biaya. Begitu juga dengan tujuan capital reduction, penerapan supply chain management diharapkan dapat meningkatkan kinerja perusahaan dengan meningkatkan tingkat pengembalian modal.

Di sisi operasional perusahaan, supply chain management akan membantu perusahaan agar barang diproduksi dan didistribusikan dalam jumlah yang tepat, lokasi yang tepat, dan dalam waktu yang tepat. Dari pernyataan itu maka dapat ditarik suatu kesimpulan bahwa supply chain management akan dapat meningkatkan kinerja operasional perusahaan. Kemudian, tujuan ketiga penerapan supply chain management yang dinyatakan oleh Siagian (2005:23) yaitu tujuan service improvement, diharapkan bahwa dengan adanya supply chain management, perusahaan dapat melakukan perbaikan layanan secara terus menerus sehingga kepuasan dan loyalitas pelanggan dapat terjaga.

Dari uraian tersebut, dapat disimpulkan bahwa supply chain management berpengaruh terhadap kinerja perusahaan. Hal tersebut didukung dengan penelitian yang telah dilakukan sebelumnya seperti Li, et al., (2006); Suharto (2013), Rahmasari (2011); Irmawati (2007); dan Ariani (2013). Dari uraian di atas, maka dirumuskan hipotesis sebagai berikut.

H1 : Supply chain management berpengaruh positif terhadap kinerja perusahaan. 
Pengaruh Supply Chain Management terhadap Keunggulan Bersaing. Keunggulan bersaing mengarah kepada kemampuan perusahaan untuk menciptakan nilai unik yang tidak dimiliki dan tidak dapat ditiru oleh pesaing (Li et al., 2006). Keunggulan bersaing pada saat ini tidak hanya ditentukan oleh kemampuan sebuah industri untuk menciptakan banyak output persatuan waktu tetapi juga menyangkut kualitas, distribusi dan layanan purna jual. Produktivitas memang penting, tetapi itu saja tidak cukup sebagai bekal untuk bersaing di pasar. Pelanggan mulai bisa membedakan produk berdasarkan kualitasnya. Bahkan disadari bahwa kualitas produk sangat bergantung pada proses produksi, manusia selaku produsen, dan sistem yang digunakan secara keseluruhan. Pengendalian kualitas tidak lagi cukup hanya dilakukan dengan model inspeksi produk, tetap lebih fundamental dengan melihat proses. Bahkan orang industri mulai sadar bahwa kualitas produk juga tidak lepas dari kualitas bahan baku yang dikirim oleh supplier (Ubud, 2009).

Supply chain management meliputi kegiatan perusahaan dalam mendapatkan bahan baku yang berkualitas, hubungan yang baik dengan supplier, kegiatan produksi yang efektif dan efisien, sistem logistik yang baik, dan pelayanan terhadap konsumen yang memuaskan. Penerapan supply chain management yang baik dapat meningkatkan nilai jual produk dan nilai perusahaan di mata konsumen baik dalam hal kualitas produk, sistem distribusi yang tepat, maupun pelayanan yang memuaskan.

Dari uraian tersebut, dapat disimpulkan bahwa supply chain management berpengaruh terhadap keunggulan bersaing perusahaan. Hal tersebut didukung oleh hasil penelitian yang lakukan oleh Li, et al., (2006); Suharto (2013); Rahmasari (2011); Bratic (2011); Henriksson dan Tom Nyberg (2005). Berdasarkan uraian di atas, hipotesis berikut diajukan :

H2 : Supply chain management berpengaruh positif terhadap keunggulan bersaing.

Pengaruh Keunggulan Bersaing terhadap Kinerja Perusahaan. Kinerja perusahaan merupakan ukuran keberhasilan suatu perusahaan yang diukur setiap jangka waktu yang ditetapkan. Hasil ini dapat dikatakan suatu nilai dari setiap aktivitas yang telah disusun dan dilaksanakan untuk dapat mengidentifikasi apakah strategi yang telah dibuat dan pelaksanaan strategi tersebut telah tepat atau malah sebaliknya (Prakosa, 2005).

Keunggulan bersaing menurut Li et al., (2006) dapat direalisasikan dengan berfokus pada harga, kualitas, delivery dependability, inovasi produk, dan time to market. Perusahaan yang berfokus pada hal tersebut akan lebih unggul dari perusahaan lainnya. Keunggulan perusahaan dibandingkan dengan pesaing dapat menarik banyak konsumen yang kemudian akan meningkatkan tingkat penjualan dan pangsa pasar perusahaan. Dengan demikian kinerja keuangan dan non keuangan perusahaan akan meningkat.

Day dan Wensley (1988) menyatakan bahwa keunggulan bersaing merupakan bentuk-bentuk strategi untuk membantu keberlangsungan hidup perusahaan. Keunggulan dalam bersaing merupakan sarana untuk mencapai tujuan akhir perusahaan yaitu meningkatkan kinerja perusahaan. Hasil penelitian lain juga mendukung pendapat Day dan Wensley (1998) tersebut, seperti Li, et al., (2006); Perry (2012); dan Rahmasari (2011). Dari uraian tersebut, maka dirumuskan suatu hipotesis tentang pengaruh keunggulan perusahaan terhadap kinerja perusahaan sebagai berikut.

H3 : Keunggulan bersaing berpengaruh positif terhadap kinerja perusahaan.

Pengaruh Supply Chain Management terhadap Kinerja Perusahaan melalui Keunggulan Bersaing. Supply chain management adalah seperangkat pendekatan yang 
diterapkan oleh perusahaan agar barang dapat diproduksi dan didistribusikan dalam jumlah yang tepat, lokasi yang tepat, waktu yang tepat dengan kualitas yang baik untuk meminimalkan biaya dan memberikan layanan yang memuaskan konsumen. Kegagalan dalam operasional perusahaan saat menghasilkan produk/jasa atau dalam level apapun dapat menyebabkan biaya kegagalan meningkat yang kemudian akan menyebabkan profitabilitas perusahaan menurun dan menyebabkan daya beli menurun pula. Dari penjelasan tersebut, dapat disimpulkan bahwa supply chain management dapat meminimalisasi biaya yang dikeluarkan oleh perusahaan dan meningkatkan nilai mutu produk di mata pelanggan.

Kinerja perusahaan dapat ditingkatkan dengan keunggulan bersaing perusahaan. Dengan terpenuhinya indikator keunggulan perusahaan seperti harga, kualitas, delivery dependability, inovasi produk, dan time to market, tingkat penjualan perusahaan akan meningkat. Selain itu, kepuasan dan loyalitas konsumen juga akan meningkat yang kemudian akan berimbas pada meningkatnya kinerja perusahaan baik keuangan maupun non keuangan. Kepuasan pelanggan, kualitas bahan baku dari supplier, dan distribusi produk dengan waktu yang tepat seakan menjadi kunci keunggulan bersaing dalam supply chain management.

Dari uraian di atas, dapat dilihat bahwa supply chain management akan mempengaruhi kinerja perusahaan melalui keunggulan bersaing perusahaan.

H4 : Supply chain management berpengaruh positif terhadap kinerja perusahaan melalui keunggulan bersaing.

Secara ringkas, model penelitian ini dapat dilihat pada gambar berikut.

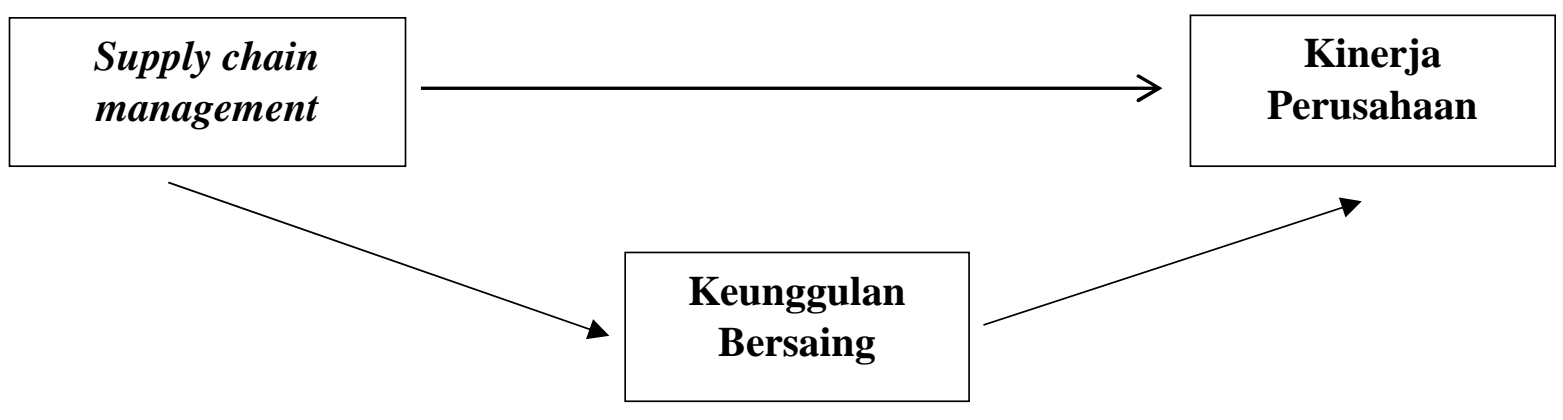

Gambar 1. Model Penelitian

\section{HASIL DAN PEMBAHASAN}

Statistik Deskripstif. Pengolahan data primer merupakan deskriptif penelitian berdasarkan pendapat responden mengenai supply chain management terhadap kinerja perusahaan melalui keunggulan bersaing pada perusahaan manufaktur yang terdaftar di Bursa Efek Indonesia tahun 2014. Analisis deskriptif untuk tiap variabel dalam penelitian ini didasarkan pada jawaban tiap pernyataan dari responden dari skala sangat tidak setuju sampai sangat setuju. Tabel descriptive statistics di bawah ini menunjukkan angka minimum, maksimum, mean, dan standar deviasi dari total jawaban responden untuk masing-masing variabel yang diukur. 
Tabel 2. Statistik Deskriptif

Descriptive Statistics

\begin{tabular}{lccccc}
\hline & N & Minimum & Maximum & Mean & Std. Deviation \\
\hline Supply Chain Management & 59 & 109,00 & 161,00 & 149,9492 & 10,64218 \\
Keunggulan Bersaing & 59 & 65,00 & 105,00 & 94,7458 & 9,33217 \\
Kinerja Perusahaan & 59 & 30,00 & 45,00 & 41,0508 & 3,83461 \\
Valid N (listwise) & 59 & & & &
\end{tabular}

Sumber: Data Olahan dengan SPSS 20.0 (2015)

Dari tabel di atas, dapat dilihat bahwa variabel statistik deskriptif masing-masing instrumen dari sebanyak 59 responden yang diteliti. Dari hasil uji statistik deskriptif, dapat disimpulkan bahwa rata-rata penerapan supply chain management pada perusahaan manufaktur yang terdaftar di Bursa Efek Indonesia (BEI) tahun 2014 sudah cukup baik yaitu sebesar 149,9492 dengan standar deviasi 6.22508, nilai minimum 109 dan nilai maksimum 161. Untuk instrumen variabel keunggulan bersaing, dapat disimpulkan bahwa rata-rata keunggulan bersaing perusahaan manufaktur yang terdaftar di Bursa Efek Indonesia (BEI) tahun 2014 adalah sebesar 94,7458 dengan standar deviasi 9,33217, nilai minimum 65 dan nilai maksimum 105. Kinerja perusahaan pada perusahaan manufaktur yang terdaftar di Bursa Efek Indonesia (BEI) tahun 2014 adalah sebesar 41,0508 dengan standar deviasi 3,83461, nilai minimum 30 dan nilai maksimum 45. Rata-rata kinerja perusahaan masih berada di bawah angka 50, hal ini menunjukkan bahwa perusahaan perlu menerapkan upaya-upaya untuk meningkatkan kinerja.

Uji Validitas dan Uji Reliabilitas. Sebelum pengujian terhadap hipotesis dilakukan, perlu dilakukan uji validitas dan uji reliabilitas terhadap instrumen penelitian. Setiap indikator instrumen yang digunakan dalam penelitian dikatakan valid jika nilai $\mathrm{r}_{\mathrm{xy}}$ (koefisien korelasi) $>\mathrm{r}_{\text {tabel }}$ (critical value). Selain itu, setiap variabel dinyatakan reliable apabila nilai Cronbach Alpha lebih besar dari 0 ,6. Dalam penelitian ini, nilai $\mathrm{r}_{\mathrm{xy}}$ (koefisien korelasi) setiap indikator instrumen lebih besar dari $\mathrm{r}_{\text {tabel }}$ (critical value). Hal ini menandakan bahwa instrumen yang digunakan dalam penelitian ini valid. Kemudian, nilai Cronbach Alpha variabel supply chain manajemen $(0,966)$, keunggulan bersaing $(0,939)$, dan kinerja perusahaan $(0,879)$ lebih besar dari 0,6 yang menunjukkan bahwa variabel memiliki reliabilitas yang baik.

Uji Asumsi Klasik. Dalam pengujian model regresi, uji asumsi klasik perlu dilakukan dalam penelitian untuk menguji apakah model regresi tersebut baik atau tidak. Dalam penelitian ini, uji asumsi klasik yang digunakan adalah uji multikolonieritas, uji normalitas, uji heteroskedastisitas, dan uji autokolerasi.

\section{Uji Multikolinieritas}

Uji multikolinearitas bertujuan untuk menguji apakah model regresi ditemukan adalanya korelasi diantara variabel bebas (independen). Model regresi yang baik seharusnya tidak terjadi korelasi diantara variabel bebas. Ada tidaknya korelasi antar variabel tersebut dapat dideteksi dengan melihat nilai Variance Inflation Factor (VIF). Hasil uji multikolinieritas dapat dilihat pada tabel berikut. 
Tabel 3. Uji Multikolinieritas

\begin{tabular}{|c|c|c|}
\hline \multicolumn{3}{|c|}{ Coefficients $^{\mathbf{a}}$} \\
\hline \multirow{2}{*}{ Model } & \multicolumn{2}{|c|}{ Collinearity Statistics } \\
\hline & Tolerance & VIF \\
\hline Supply Chain Management & 0,200 & 5,009 \\
\hline Keunggulan Bersaing & 0,200 & 5,009 \\
\hline
\end{tabular}

Dependent variable : Kinerja Perusahaan

Sumber: Data Olahan dengan SPSS 20.0 (2015)

Dari tabel di atas diperoleh nilai VIF untuk seluruh variabel bebas $<10$ dan tolerance $>$ 0,10 . Hal ini dapat disimpulkan bahwa model regresi tersebut bebas dari multikolinearitas.

Uji Normalitas. Uji normalitas bertujuan untuk menguji apakah variabel terikat dan variabel bebas dalam model regresi mempunyai distribusi normal atau tidak. Model regresi yang baik adalah yang memiliki distribusi normal atau mendekati normal. Uji normalitas data menggunakan Kolmogorov-Smirnov Test dengan membandingkan Asymptotic Significance $\alpha=5 \%$. Dasar penarikan kesimpulan adalah data dikatakan distribusi normal apabila Asymptotic Significance >0,05 (Santoso, 2010:46). Hasil uji normalitas pada penelitian ini dapat dilihat pada tabel berikut.

Tabel 4. Uji Normalitas dengan Kolmogorov-Smirnov Test

\section{One-Sample Kolmogorov-Smirnov Test}

\begin{tabular}{lrr}
\hline & & Unstandardized Residual \\
Normal Parameters ${ }^{\mathrm{a}, \mathrm{b}}$ & Mean & 59 \\
& Std. Deviation & 0,0000000 \\
Most Extreme & Absolute & 2,04371945 \\
Differences & Positive & 0,134 \\
& Negative & 0,127 \\
& Kolmogorov-Smirnov Z & $-0,134$ \\
& Asymp. Sig. (2-tailed) & 1,026 \\
& & 0,244 \\
\hline
\end{tabular}

a. Test distribution is Normal.

b. Calculated from data.

Sumber: Data Olahan dengan SPSS 20.0 (2015)

Dari Tabel 4 diperoleh Asymptotic Significances sebesar 0,244>0,05. Dengan demikian maka model regresi memenuhi asumsi normalitas.

Uji Heteroskedastisitas. Uji Heteroskedastisitas bertujuan untuk menguji apakah model regresi terjadi ketidaksamaan variance dari residual satu pengamatan ke pengamatan yang lain. Model regresi yang baik adalah tidak terjadinya heteroskedastisitas. Untuk mendeteksi ada atau tidaknya heteroskedastisitas dapat dilakukan dengan melihat grafik 
Plot. Adapun hasil pengujian heterokedastisitas penelitian ini dapat dilihat pada gambar berikut.

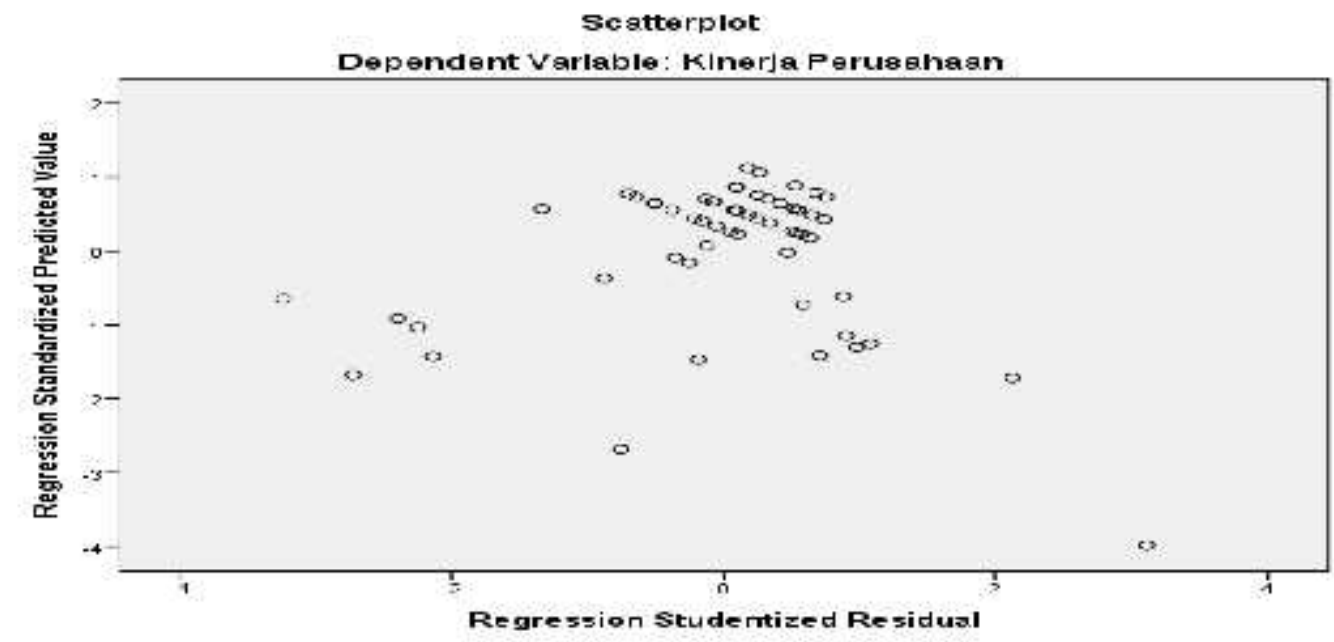

Gambar 2. Uji Heteroskedastisitas

Berdasarkan gambar di atas dapat dilihat bahwa titik-titik menyebar di atas dan di bawah angka 0 pada sumbu Y serta tidak ada pola yang jelas yang dibentuk oleh titik-titik tersebut. Dengan demikian dapat disimpulkan bahwa model regresi ini memenuhi asumsi heteroskedastisitas. Dengan kata lain pada model regresi ini terdapat variasi data homoskedastisitas.

Uji Autokorelasi. Tujuan uji autokorelasi adalah untuk mengetahui apakah dalam sebuah model regresi linear ada korelasi antara kesalahan pengganggu pada periode $t$ dengan kesalahan pada periode t-1 (sebelumnya). Untuk mendeteksi ada tidaknya autokorelasi dapat dilihat dari nilai Durbin Watson (DW). Jika angka DW di bawah -2, maka terdapat autokorelasi positif. Jika angka DW diantara -2 sampai +2 , maka tidak terdapat autokorelasi. Jika DW di atas +2 , maka terdapat autokorelasi negatif. Hasil pengujian autokorelasi dari penelitian ini dapat dilihat dari tabel berikut.

Tabel 5. Uji Autokolerasi

\begin{tabular}{llcrrr}
\multicolumn{5}{c}{ Model Summary $^{\mathbf{b}}$} \\
\hline Model & R & R Square & Adjusted R Square & $\begin{array}{c}\text { Std. Error of the } \\
\text { Estimate }\end{array}$ & Durbin-Watson \\
\hline 1 & $0,828^{\mathrm{a}}$ & 0,686 & 0,675 & 2,18756 & 1,289 \\
\hline
\end{tabular}

a. Predictors: (Constant), Supply Chain Management, Keunggulan Bersaing

b. Dependent Variable: Kinerja Perusahaan

Sumber: Data Olahan dengan SPSS 20.0 (2015)

Berdasarkan hasil di atas diketahui nilai $\mathrm{d}_{\text {hitung }}$ (Durbin Watson) terletak antara -2 dan $2=-2<1,289<2$. Dapat disimpulkan bahwa tidak ditemukannya autokorelasi dalam model regresi. 
Uji F. Uji F pada dasarnya menunjukkan apakah semua variabel bebas yang dimasukkan dalam model mempunyai pengaruh secara bersama - sama terhadap variabel dependen. Uji $\mathrm{F}$ dilakukan dengan membandingkan nilai $F_{\text {hitung }}$ dengan $F_{\text {tabel }}$. Kriteria pengujian adalah jika $F_{\text {hitung }} \leq \mathrm{F}_{\text {tabel}}$, artinya variabel independen secara simultan tidak berpengaruh terhadap variabel dependen. Sebaliknya, jika $F_{h i t u n g}>F_{\text {tabel }}$ artinya variabel independen secara simultan berpengaruh terhadap variabel dependen. Hasil uji $\mathrm{F}$ dapat dilihat pada tabel berikut.

Tabel 6. Uji F

\begin{tabular}{|c|c|c|c|c|c|c|}
\hline \multicolumn{7}{|c|}{ ANOVA $^{\mathrm{a}}$} \\
\hline Model & & $\begin{array}{l}\text { Sum of } \\
\text { Squares }\end{array}$ & Df & $\begin{array}{l}\text { Mean } \\
\text { Square }\end{array}$ & $\mathrm{F}$ & Sig. \\
\hline \multirow{3}{*}{1} & & 584.864 & 2 & 292.432 & 61.109 & $.000^{\mathrm{b}}$ \\
\hline & Kegression & 267.983 & 56 & 4.785 & & \\
\hline & $\begin{array}{l}\text { Residual } \\
\text { Total }\end{array}$ & 852.847 & 58 & & & \\
\hline
\end{tabular}

a. Dependent Variable : Kinerja Perusahaan

b. Predictors : (Constant), Keunggulan Bersaing, Supply Chain Management

Sumber: Data Olahan dengan SPSS 20.0 (2015)

Berdasarkan hasil yang ditampilkan pada tabel di atas dapat dilihat bahwa nilai $\mathrm{F}_{\text {hitung }}$ lebih besar dari nilai $\mathrm{F}_{\text {tabel }}(61.109>3.16)$ sehingga dapat disimpulkan bahwa variabel independen secara simultan berpengaruh terhadap variabel dependen.

Uji Koefisien Determinasi $\left(\mathbf{R}^{2}\right)$. Koefisien determinasi $\left(\mathrm{R}^{2}\right)$ pada intinya untuk mengukur seberapa jauh kemampuan model dalam menerangkan variasi variabel terikat (Kuncoro, 2013:246). Koefisien determinasi menjelaskan seberapa jauh suatu variabel bebas menentukan perubahan nilai variabel terikat dapat diketahui. Besarnya koefisien determinasi terletak antara nol dan satu (Santosa dan Muliawan, 2007:256).

Koefisien determinasi digunakan untuk mengetahui kemampuan variabel independen dalam menjelaskan variabel dependen. Nilai koefisien determinasi adalah diantara nol dan satu. Semakin tinggi nilai koefisien determinasi semakin baik. nilai $\mathrm{R}^{2}$ yang kecil berarti kemampuan variabel-variabel independen dalam menjelaskan variasi variabel dependen amat terbatas. Nilai determinasi yang mendekati satu berarti variabelvariabel memberikan semua hampir semua informasi yang dibutuhkan untuk memprediksi variasi variabel dependen. Hasil analisis determinasi dapat dilihat pada output Model Summary berikut.

Tabel 7. Uji Koefisien

Model Summary

\begin{tabular}{lrrrr}
\hline Model & R & R Square & $\begin{array}{c}\text { Adjusted R } \\
\text { Square }\end{array}$ & Std. Error of the Estimate \\
\hline 1 & $.825^{\mathrm{a}}$ & .681 & .672 & 2,18490 \\
\hline
\end{tabular}

a. Predictors: (Constant), Supply Chain Management, Keunggulan Bersaing

b. Dependent Variable: Kinerja Perusahaan

Sumber: Data Olahan dengan SPSS 20.0 (2015) 
Hasil uji analisis pada tabel di atas, diperoleh nilai R Adjusted Square sebesar 0.672 atau $67.2 \%$. Hal ini menunjukkan bahwa persentase sumbangan pengaruh variabel independen (supply chain management) dan invervening (keunggulan bersaing) terhadap variabel dependen (kinerja perusahaan) sebesar 67.2\% dengan kata lain nilai tersebut menunjukkan bahwa secara keseluruhan variabel bebas hanya mempengaruhi $67.2 \%$ variabel terikat. Sisanya dipengaruhi oleh variabel lain diluar model penelitian ini.

Uji Hipótesis.Berdasarkan hasil analisis, maka dapat diketahui pengaruh antara variabel independen secara parsial terhadap variabel dependen pada tabel uji hipotesis berikut. Dari tersebut, dapat dilihat bahwa $t_{\text {hitung }}>t_{\text {tabel }}$ dan nilai sig $<\alpha 0,05$. Hal ini menunjukkan bahwa ketiga hipotesis dalam penelitian ini diterima. Penelitian ini dapat membuktikan bahwa supply chain management berpengaruh positif terhadap kinerja perusahaan dengan nilai $t_{\text {hitung }}(11,030)$ yang lebih besar dari nilai $t_{\text {tabel }}(1,67)$ dan nilai signifikan 0,000 . Hal ini berarti bahwa semakin tinggi tingkat penerapan supply chain management maka kinerja perusahaan akan meningkat. Penelitian ini juga membuktikan bahwa supply chain management berpengaruh positif terhadap keunggulan bersaing yang dapat dilihat dari nilai thitung yang lebih besar dari nilai tabel $(15,116>1,67)$ dengan nilai signifikan $0,000 \mathrm{Hal}$ ini berarti bahwa semakin tinggi penerapan supply chain management maka perusahaan akan semakin unggul dari pesaing. Selain itu, penelitian ini juga membuktikan bahwa keunggulan bersaing berpengaruh positif terhadap kinerja perusahaan dengan nilai signifikan 0,000 dan nilai thitung $(7,551)$ yang lebih besar dari nilai $t_{\text {tabel }}(1,67)$. Hal ini membuktikan bahwa semakin unggul perusahaan dari pesaing, semakin bagus kinerja perusahaan tersebut.

Tabel 8. Hasil Regresi Berganda

\begin{tabular}{llccccc}
\hline $\begin{array}{l}\text { Variabel } \\
\text { Independen }\end{array}$ & $\begin{array}{l}\text { Variabel } \\
\text { Dependen }\end{array}$ & \multicolumn{2}{c}{$\begin{array}{c}\text { Unstandardized } \\
\text { Coefficients }\end{array}$} & $\begin{array}{c}\text { Standardized } \\
\text { Coefficients }\end{array}$ & T & Sig. \\
\cline { 3 - 5 } & & B & Std. Error & Beta & & \\
\hline SCM & KP & .297 & .027 & .825 & 11.030 & .000 \\
SCM & KB & .784 & .052 & .895 & 15.116 & .000 \\
KB & KP & .291 & .038 & .707 & 7.551 & .000 \\
\hline
\end{tabular}

Sumber: Data Olahan dengan SPSS 20.0 (2015)

Catatan: SCM : Supply Chain Management; KB: Keunggulan Bersaing; KP : Kinerja Perusahaan

Untuk menguji hipotesis keempat, dilakukan langkah-langkah pengujian seperti yang disarankan oleh Frazier et al., (2004) sebagai berikut : (1) Menunjukkan adanya hubungan yang signifikan antara variabel independen (supply chain management) dengan variabel dependen (kinerja perusahaan); (2) Menunjukkan adanya hubungan signifikan bantara variabel independen (supply chain management) dengan variabel intervening (keunggulan bersaing);(3) Menunjukkan adanya hubungan yang signifikan antara variabel intervening (keunggulan bersaing) dengan variabel dependen (kinerja perusahaan);(4) Menunjukkan bahwa berkurangnya kekuatan hubungan antara variabel independen (supply chain management) dengan variabel dependen (kinerja perusahaan) setelah dimasukkan variabel intervening (keunggulan bersaing) ke dalam model. Jika setelah dimasukkannya variabel intervening (keunggulan bersaing) ke hubungan antara variabel independen (supply chain management) dengan variabel dependen (kinerja perusahaan) menjadi 0, maka variabel 
intervening berperan sebagai full mediation, sementara itu apabila setelah dimasukkannya variabel intervening (keunggulan bersaing) ke hubungan antara variabel independen (supply chain management) dengan variabel dependen (kinerja perusahaan) menjadi berkurang dari sebelumnya, maka variabel intervening berperan sebagai partial mediation.

Tabel berikut menyajikan hasil regresi untuk menguji peran keunggulan bersaing sebagai variabel intervening. Sesuai dengan saran Frazier et al., (2004) pada langkah pertama, supply chain management terbukti memiliki pengaruh terhadap kinerja perusahaan $(\beta=0,825, \rho=0,000)$, dengan demikian kriteria pertama untuk menguji variabel intervening telah terpenuhi. Pada langkah kedua, supply chain management terbukti memiliki pengaruh terhadap keunggulan bersaing $(\beta=0,892, \rho=0,000)$, dengan demikian kriteria kedua untuk menguji variabel intervening telah terpenuhi. Pada langkah ketiga, keunggulan bersaing terbukti memiliki pengaruh terhadap kinerja perusahaan $(\beta=$ 0,707, $\rho=0,000$ ), dengan demikian kriteria ketiga untuk menguji variabel intervening telah terpenuhi. Pada langkah keempat, nilai $\beta$ yang menunjukkan pengaruh supply chain management terhadap kinerja perusahaan setelah dimasukkannya variabel keunggulan bersaing menjadi lebih kecil dari 0,825 menjadi 0,412. Dengan demikian, variabel keunggulan bersaing merupakan variabel yang berperan sebagai partial mediation. Hal ini berarti, pada sebagian perusahaan supply chain management dapat mempengaruhi kinerja perusahaan secara tidak langsung melalui keunggulan bersaing, namun bagi sebagian lainnya, supply chain management dapat mempengaruhi kinerja perusahaan secara langsung.

Tabel 9. Hasil Pengujian Variabel Intervening

\begin{tabular}{clll}
\hline Variabel & \multicolumn{1}{c}{ SCM } & \multicolumn{1}{c}{ KB } & \multicolumn{1}{c}{ KP } \\
\hline KP & Langkah & Langkah ketiga & \\
& pertama & $\beta=0,707$ & \\
& $\beta=0,825$ & $\rho=0,000$ & \\
& $\rho=0,000$ & (signifikan) & \\
& (signifikan) & & \\
& Langkah & & Langkah \\
KB & kedua & & keempat \\
& $\beta=0,892$ & & $\beta=0,412$ \\
& $\rho=0,000$ & & $\rho=0,000$ \\
& (signifikan) & & (signifikan) \\
\hline
\end{tabular}

Sumber : Data Olahan dengan SPSS 20.0 (2015)

Catatan : SCM: Supply Chain Management; KB : Keunggulan Bersaing; KP : Kinerja Perusahaan

\section{PENUTUP}

Simpulan. Hasil pengujian hipotesis menunjukkan bahwa semua hipotesis yang diajukan dalam penelitian ini dapat diterima. Supply chain management berpengaruh positif terhadap kinerja perusahaan. Hal ini menunjukkan bahwa semakin tinggi tingkat penerapan supply chain management di dalam suatu perusahaan akan menghasilkan kinerja perusahaan yang semakin baik pula. Penelitiam ini menemukan bahwa supply chain management berpengaruh positif terhadap keunggulan bersaing. Hal ini 
menunjukkan semakin tinggi tingkat penerapan supply chain management di dalam suatu perusajaan maka perusahaan tersebut akan semakin unggul dari perusahaan lainnya. Hasil penelitian ini membultikan bahwa keunggulan bersaing memberikan efek positif terhadap kinerja perusahaan. Hal ini menunjukkan bahwa semakin unggul suatu perusahaan dari perusahaan lainnya, maka kinerja perusahaan tersebut akan semakin meningkat. Selanjutnya penelitian menemukan bahwa pengaruh supply chain management terhadap kinerja perusahaan dimediasi oleh keunggulan bersaing. Dalam penelitian ini juga ditemukan bahwa variabel keunggulan bersaing berperan sebagai partial mediation variable.

Saran. Penelitian ini telah berhasil membuktikan hipotesis yang diajukan. Walau bagaimanapun disadari adanya keterbatasan-keterbatasan dalam penelitian ini. Pada penelitian ini hanya berfokus pada perusahaan manufaktur yang terdaftar di Bursa Efek Indonesia (BEI) 2014 sehingga hasil penelitian ini mungkin tidak dapat digeneralisasi kepada industri lainnya. Di samping itu, data penelitian ini relatif kecil. Oleh karena itu, penelitian selanjutnya dapat meneliti ulang dengan meneliti pada industri yang lain seperti seperti industri jasa atau industri retail dan memperluas jumlah sampel. Penelitiam selanjutnya dapat melihat variabel antesen bagi supply chain management sehingga hasil penelitian berikutnya dapat memperluas pemahaman mengenai supply chain management dan kaitannya dengan kinerja perusahaan.

\section{DAFTAR RUJUKAN}

Anthony, Robert N dan Vijay Govindarajan. (2012) Sistem Pengendalian Manajemen. Edisi 11 Buku 1. Jakarta: Salemba Empat.

Ariani, Desi. (2013) “Analisis Pengaruh Supply Chain Management terhadap Kinerja Perusahaan”. Skripsi, pada Fakultas Ekonomika Dan Bisnis Universitas Diponegoro Semarang.

Carton, Robert B. (2004) Measuring Organizational Peformance: An Explaratory Study. A Dissertation Submitted to the Graduate Faculty of The University of Georgia in Partial.

Chairany, Nurul dan Wahyuni Lestari. (2011) "Pengaruh Total Quality Management terhadap Kinerja Perusahaan melalui Kepemimpinan dan Perilaku Produktif Karyawan". Skripsi.

Day, George dan Wensley, Robin. (1988) "Assessing Advantage: A Framework for Dianostic Competitive Superiority". Journal of Marketing, Vol.52, April.

Frazier, A.P., K.E Barron, \& A.P Tix. (2004) "Testing Moderator and Mediator Effects in Counseling Psychology Research". Journal of Counseling Psychology, 51(1): 115134.

Heizer, Jay., \& Barry Render, (2004) Operation Management. New Jersey: Pearson Education, Inc. 7th Editions.

Henriksson, Toni dan Tom Nyberg. (2005) "Supply Chain Management as a Source of Competitive Advantage". Master Thesis, in Business Administration Management Accounting School of Economics and Commercial Law.

Irmawati. (2007) "Pengaruh Manajemen Rantai Pasokan Terhadap Kinerja Di Ptpn VIII Gunung Mas Bogor". Skripsi, pada Fakultas Ekonomi dan Manajemen, Institut Pertanian, Bogor. 
Jahanshahi, A. A., Rezaie, M., Nawaser, K., Ranjbar, V., \& Pitamber, B. K. (2012) "Analyzing the Effect of Elevtronic Commerce on Organizational Performance : Evidence from Small and Medium Enterprises". African Journal of Bussiness Management, 6 (15): 6486-6496.

Kuncoro, Mudrajad. (2013) Metode Riset untuk Bisnis dan Ekonomi. Bagaimana Meneliti dan Menulis Tesis? Edisi 4. Jakarta : Erlangga.

Levi, David Simchi, Philip Kamin Sky \& Edith Simchi Levi. (2000) Designing And Managing The Supply Chain : Concept, Strategies And Case Studies. Singapore : Irwin McGraw-Hill.

Li, Suhong, Bhanu Ragu-Nathan, T.S. Ragu-Nathan, dan S. Subba Rao. (2006) "The impact of supplychain management practices on competitive advantage and organizational performance". The International Journal of Management Science. (Retrifed from www.sciencedirect.com).

McLeod, Jr., Raymond dan George P.Schell. (2011) Sistem Informasi Manajemen. Edisi 10. Jakarta: Salemba Empat.

Perry II, John F. BS dan Captain, USAF. (2012) "The Impact Of Supply Chain Management Business Processes On Competitive Advantage And Organizational Performance". Thesis, AFIT/LSCM/ENS/12-14.

Porter, Michael, E. (1985) Competitive Advantage: Creating and Sustaining superior Performance. New York : Free Press.

Prakosa, Bagas. (2005) Pengaruh Orientasi Pasar, Inovasi, dan Orientasi Pembelajaran terhadap Kinerja Perusahaan untuk Mencapai Keunggulan Bersaing. Jurnal Studi Manajemen dan Organisasi, 2 (1): Januari .

Prayhoego, Callystha dan Devie, (2013) "Pengaruh Total Quality Management terhadap Keunggulan Bersaing dan Kinerja Organisasi”. Business Accounting Review, Vol. 1.

Rahmasari, Lisda. (2011) "Pengaruh Supply Chain Management Terhadap Kinerja perusahaan dan Keunggulan Bersaing”. Majalah Ilmiah INFORMATIKA, 2 (3), September.

Santosa, Purbayu Budi dan Muliawan Hamdani. (2007) Statistika Deskriptif dalam Bidang Ekonomi dan Niaga. Jakarta: Erlangga

Santoso, Singgih. (2010) Statistik Multivariat Konsep dan Aplikasi dengan SPSS . Jakarta: PT. Elex Media Komputindo.

Sekaran, Uma. (2009) Research Methods for Business. Edisi 4. Jakarta: Salemba Empat.

Siagian, Y.M. (2005) Aplikasi Supply Chain Management dalam Dunia Usaha. Grasindo : Jakarta.

Sugiono. (2012) Metode Penelitian Bisnis. Bandung : Alfabeta.

Suhartati, Titi dan Hilda Rosietta. (2012) Pengaruh Strategi Bersaing terhadap Hubungan antara Supply Chain Management dan Kinerja.

Suharto, Regina dan Devie. (2013) "Analisa Pengaruh Supply Chain Management terhadap Keunggulan Bersaing dan Kinerja Organisasi". Business Accounting Review. 1 (2).

Ubud, Sahnaz. (2009) "Peningkatan Keunggulan Bersaing melalui Supply Chain Flexibility beserta Variabel Antecedentnta pada Industri Manufaktur di Jawa Timur". Jurnal Aplikasi Manajemen, 7 (3), Agustus.

Venkatraman, N. \& Ramanujam, V. (1986) "Measurement of Business Performance in Strategy Research: A Comparison of Approaches". Academy Management Review, 11(4): 801-814. 
Bratic, Diana. (2011) “Achieving a Competitive Advantage by SCM". IBIMA Business Review. Vol. 2011 (2011), Article ID 957583, 13 pages. (Retrifed from: http://www.ibimapublishing.com/journals/IBIMABR/ibimabr.html 12 Maret 2015)

CNN Indonesia. 2014. (Retrifed from http://www.cnnindonesia.com/ekonomi/20141103130554-92-9418/manufakturindonesia-tumbuh-496-/07 Maret 2015)

Yurniwati. Kinerja perusahaan diukur dengan balance scorecard. (Retrifed from : http://www.damandiri.or.id/file/yurniwatiunpadbab2.pdf 17 Maret 2015) 